\title{
Power, Structural Power, and American Decline
}

\section{Nicholas Kitchen}

University of Surrey

n.kitchen@surrey.ac.uk

\section{Michael Cox}

LSE IDEAS, London School of Economics

m.e.cox@1se.ac.uk

\begin{abstract}
Over the past twenty years, debates surrounding American power have oscillated between celebrations of empire and laments of decline. What explains such wild fluctuations? This article argues that the power shifts debate rests on an underpinning concept of power based around relative capabilities that is theoretically not fit for purpose. We propose instead an approach to power shifts that locates power primarily in structural power. In doing so we show that developments in the character of the international system render structural advantage more significant to questions of international leadership than the balance of national capabilities. These developments also mitigate against systemic changes that might bring relative strength and structural position into greater alignment.
\end{abstract}




\section{Introduction}

Herodotus had a sobering observation of the ebbs and flows of wealth and power. "Human prosperity," he wrote, "never abides long in the same place" (De Selincourt \& Marincola, 2003, p. 5). In the debate surrounding American decline, prosperity and power's restlessness in time has reflected the constantly travelling centre of world economic gravity to establish a basic truth: that power is shifting - either away from the West more generally or from the United States in particular (Quah, 2011). For the most bearish, the United States' 'failed empire' (Mann, 2004) will be replaced by an 'Asian Century' (Mahbubani, 2008) in which the Washington Consensus is replaced by Beijing's state capitalism (Halper, 2010) and 'China rules the world' (Jacques, 2009). Other, more circumspect, authors see in the reality of a 'post-American world' (Zakaria, 2008) the giving way of the temporary condition of unipolarity (Layne, 2012), to be replaced by a 'G-zero' international order (Bremmer, 2012) in which emerging powers play an increasing significant role (Wilson \& Purushothaman, 2003) but superpowers are conspicuous by their absence (Buzan, 2011). Still others push back more forcefully at the notion of American decline, both from academic positions (Joffe 2014; Nye Jr, 2015; Beckley 2018), as a matter of electioneering (Romney, 2010), and for the previous US President, in defence of his administration (Obama, 2016).

Yet despite such vibrant debate, the theoretical underpinnings of protagonists' positions have often been neglected. Few have sought to think conceptually about how to systematically interrogate whether a power shift is in fact taking place (Cox, 2011). Prominent contributions rarely engage the question of what power is and how it might be measured, and those that do offer only limited engagement with the conceptual literature on power (Joffe, 2014). This highly unsatisfactory situation reflects the fact that power, despite its central importance to the discipline of International Relations, "is one of the most under-researched concepts in the discipline" (Guzzini, 2000, p. 53). ${ }^{1}$

This paper seeks to better connect the decline debate to the existing conceptual literature on power. In particular, it points to the difference between the relative power of states assessed in terms of capabilities - the dominant, if implicit, conceptual underpinning of the power shifts literature - and structural power, which describes the balance of advantage built into systems of states' interaction. We argue that it is structural power - not relational capabilities - that is determining of international leadership. In doing so, we emphasise how ephemeral rise and fall narratives are, and affirm how stubbornly resistant to change international order is.

The argument proceeds in three stages. First, we briefly review the cycles of the decline debate, showing that arguments about decline have repeatedly run further and faster than underpinning power realities. Second, we unpack the conceptual approach to power operationalised in the decline debate, in which capabilities are assumed to provide states with the ability to control outcomes - the essence of the Dahlian behavioural definition of power. As Guzzini notes, given that IR associates a general capacity to control outcomes with notions of ruling the international system, the decline debate posits a double causal link between capabilities and international leadership (Guzzini, 2000). In this section we take issue with both of these causal claims, and argue that the desire for an aggregate assessment of relational power faces insurmountable conceptual challenges. In the third section, we review the concept of structural power, and show how ideological and technological developments in the international system in the $20^{\text {th }}$ Century both render structural advantages more significant to questions of international leadership than the

\footnotetext{
${ }^{1}$ It is notable, and perhaps surprising, that scholars concerned with theoretical and empirical challenges of power analysis have scarcely engaged with the decline debate, and International Relations has remained largely resistant to engaging research from that field (see Baldwin, 2016).
} 
balance of relative national capabilities, and mitigate against systemic changes that might bring relative strength and structural position into greater alignment.

\section{The Rise, Fall, and Rise of American Decline}

Those arguing that the United States is now in decline are joining a long history of commentary. The first doubts about Henry Luce's 'American Century' were engendered by Soviet technological successes as soon as the 1950s, before domestic civil strife, the Vietnam War and the international political economy of the 1970s prompted calls for America to manage rather than resist the process of its inexorable decline (Hoffmann, 1978). That Reagan could pronounce 'morning in America' seemed only to confirm that the nation had lost its way, a drift derived from political malaise, economic sickness or moral torpor depending on one's point of view. ${ }^{2}$

Reagan's optimism proved short-lived. Paul Kennedy's The Rise and Fall of the Great Powers hit bookstores at the height of the late-80s boom, in the same year that Oliver Stone's $W$ all Street brought the extravagance of the heights of American capitalism to the silver screen. Kennedy's wealth of quantitative data underpinned a simple argument: that great powers fell as surely as they rose, and the United States would be no different (Kennedy, 1987). America's commitments would outstrip its ability to pay for them, and out of indebtedness would come inevitable decline. Reagan's military buildup and the booming stock market signalled not strength but weakness, fuelled as they had been by massive federal budget deficits.

The 1990s seemed to prove Kennedy wrong, casting declinists as the "boys who cried wolf" (Nau, 2001) and confirming their role in stimulating processes of renewal (Huntington, 1988). In less than a decade the narrative about American decline was replaced by notions of American empire. The United States' economic and technological dominance allowed it to sustain a command of the commons as no other nation had done before, rendering unipolarity stable (Wohlforth, 1999; Posen, 2003). Even after 9/11, the invasions first of Afghanistan and then of Iraq demonstrated a capacity to act unilaterally that only confirmed American dominance (Ali, 2003). Even Kennedy rowed back from a declinist position (Kennedy, 2002). The United States was a new liberal empire (Cox, 2001).

Only a few years later, the United States' expensive military adventures revived warnings of imperial overstretch (Burbach \& Tarbell, 2004; Murphy, 2007), and stimulated celebration from the left at the impending demise of the American empire (Wallerstein, 2003). The unmasking of American military power was reinforced by suspicions about the United States' economy and the Federal government's finances. The massive ongoing costs of the war on terror (Stiglitz \& Bilmes, 2008) combined with tax cuts that proved not to be the spur to growth their proponents believed, to once again raise the sceptre of persistent deficits (Morgan, 2009, pp. 206-249). When the financial crisis exposed the fragility of the American economy and necessitated massive government intervention, one longer-term analysis describing the post-2020 fiscal outlook as 'downright apocalyptic' (Altman \& Haass, 2010).

However, as with America's post-9/11 wars, the fallout from the economic policies that financed them fell disproportionately outside the United States. With global confidence low, the market for US debt remained robust even as the Federal Reserve inflated away the value of dollar assets, much to the annoyance of Beijing, the United States' largest creditor, which was reduced to rhetoric that amounted to "a plea that someone rescue China from its own investment mistakes" (Krugman, 2009). That the United States could export its recessions as well as its wars had broader consequences for US prestige. The United States' claims to moral leadership, and the liberal (and

\footnotetext{
${ }^{2}$ On the sources and evolution of the decline debate see Cox (2001b; 2007).
} 
neoconservative) notions of benign hegemony that had dominated the 1990s, lost much of their lustre, even among longstanding friends and allies (Habermas, 2003; Kitchen \& Cox, 2011). The US model of capitalism, previously so dominant, had produced levels of inequality that constrained growth, corrupted politics, and undercut America's attractiveness as a society; it at last seemed open for challenge (Gray, 2009, pp. xi-xxv; Stiglitz, 2012). This time, the Chief Foreign Correspondent of London's Financial Times argued, American decline was real (Rachman, 2011).

And yet, as surely as Kennedy's thesis had been jettisoned in the 1990s, as the Obama years wore on the narrative began to push back. That the world looked to the United States to stabilise the global economy after the financial crisis, and markets sought to purchase Federal debt at negative real interest rates, confirmed the United States as the 'default' hegemonic power (Joffe, 2009; Drezner, 2009; 2014; Norrlof, 2010). America's prospects, assessed in relation to those of its nearest prospective challenger, looked rosier, since we had come to 'The End of China's Rise' (Lynch, 2016).

Despite this revision of elite narratives, China's challenge to American prosperity persisted and flourished in Trump's populist telling, with $49 \%$ of Americans doubting US military pre-eminence (Zenko, 2016). Globalist elites - in both of America's dominant political parties - had made 'bad deals', the United States did not 'win anymore'. Decline was a stark - and dark - underpinning logic of the victorious Republican campaign, and 'America First' was a strategy to arrest it (Trump 2017). Driven to explain Trump's unexpected success, academics and commentators turned their focus to the erosion of dominant economic and cultural power structures (Inglehart and Norris 2016; Hochschild 2016). Once in government, Trump's trampling of constitutional norms and democratic institutions, and the damage to America's reputation abroad, prompted fresh concerns that the American era could be coming to an end (Cohen 2017). For Jonathan Kirshner - no apologist for US hegemony - that damage would prove irreversible: "We have lost, we are lost. Not an election, but a civilization.” (Kirshner 2017).

\section{Concepts and Data: Measuring Power}

What do the cycles of this decline debate really tell us about power and influence in the world? It simply strains credibility to believe that power might shift as rapidly as these shifting narratives suggest. Indeed, assessments about such trends are often at odds on the most basic questions of what decline means. Consider Barack Obama's rubbishing of declinism in his 2016 State of the Union address:

"Let me start with the economy, and a basic fact: The United States of America, right now, has the strongest, most durable economy in the world. We're in the middle of the longest streak of private sector job creation in history. More than 14 million new jobs, the strongest two years of job growth since the ' $90 \mathrm{~s}$, an unemployment rate cut in half. Our auto industry just had its best year ever. That's just part of a manufacturing surge that's created nearly 900,000 new jobs in the past six years. And we've done all this while cutting our deficits by almost three-quarters $(. .$.

Anyone claiming that America's economy is in decline is peddling fiction. Let me tell you something. The United States of America is the most powerful nation on Earth. Period. It's not even close. We spend more on our military than the next eight nations combined. Our troops are the finest fighting force in the history of the world. No nation attacks us directly, or our allies, because they know that's the path to ruin. Surveys show our standing around the world is higher than when I was elected to this office, and when it comes to 
every important international issue, people of the world do not look to Beijing or Moscow to lead - they call us." (Obama 2016)

On the economy, Obama uses a formulation that amounts to "these things are improving, therefore the United States can't be in decline". On military matters, the formulation changes, to become "the gap is large, therefore the United States can't be in decline". And on America's reputation and standing, the formulation becomes "we're the only option, therefore the United States can't be in decline". Swapping between formulations isn't just a feature of presidential speech writing. As Michael Beckley notes, in the decline debate "most studies do not look at a comprehensive set of indicators. Instead they paint impressionistic pictures of the balance of power, presenting titbits of information on a handful of metrics" (Beckley, 2011). Little, it seems, has changed since the 1980s iteration of the debate, when Samuel Huntington complained that "declinist writings do not elaborate testable propositions involving independent and dependent variables” (Huntington, 1988).

There are comprehensive studies of capabilities within the decline debate (Heginbotham et. al., 2015; Brooks \& Wohlforth, 2016), but little that is critically self-reflective on the relationship between their analysis of particular indicators and power itself. Some power analysis takes seriously the issue of perception of power independent of the actual capabilities from which it derives (Friedberg, 1988; Leffler, 1992; Wohlforth, 1993), but these tend to theorise 'mistakes' in developing foreign policy in response to power, rather than probing the reliability of power indicators themselves (Merritt and Zinnes 1988). Yet the clarity with which we can perceive power shifts depends on the availability and quality of indicators, and the extent to which they accurately represent capabilities, as much as it does the analysis of them.

Although, as William Wohlforth notes, "these complications in measuring power are obvious to anyone with any knowledge of international history" (Wohlforth, 2003, p.254), realists have tended to simultaneously acknowledge this difficulty and at the same time press ahead with attempts to quantitatively assess the balance of power. A RAND Corporation study, Measuring National Power in the Postindustrial Age, notes that "it is not always clear which resources are appropriate as measures of real power, or whether the resources nominally possessed in any given instance are actually usable by the actor in question". "Despite these difficulties" the report continues "the concept of power as resources has remained attractive enough and will not be easily discarded". No attempt is made to overcome these basic conceptual problems, and the authors blithely continue to construct a 'minimally necessary' set of quantitative indicators of national power (Tellis et. al, 2000). Stefano Guzzini, who, along with David Baldwin, has perhaps done most to get IR to treat the concept of power seriously, notes that as far back as 1969, Daniel Frei had insisted that power is all a matter of perception, and could not be objectively measured. "The discipline nonetheless pursued its quest for an objective measure of power as the basis for interacting with the world of practitioners. By doing so (...) it misconceived and hence misused the concept of power" (Guzzini, 2009, p.5).

This misuse of the concept of power in the decline debate is expressed by its view of power as a property concept, that is, related to resources. Resource-based accounts of power seek to avoid the 'exercise fallacy', that is, to equate power simply with the act of changing another actor's behaviour. Capabilities approaches, however, are vulnerable to the 'vehicle fallacy', that is, they treat power as a resource, forgetting that "resources are the media through which power is exercised" (Giddens 1979, p.91). In advancing a dispositional understanding of power, Peter Morriss seeks to avoid this problem. For Morriss, power is "neither a thing (a resource or vehicle) nor an event (an exercise of power): it is a capacity". He quotes the philosopher Anthony Kenny's consideration of the capacity of whisky to intoxicate: the whisky has this capacity whilst in the 
bottle, but only begins to exercise it once drunk; the vehicle of whisky's capacity to intoxicate is the alcohol it contains (Morriss, 2002, pp.14-19).

However, a dispositional understanding of power as a capacity does not resuscitate resource-based analysis, for two, related reasons. First, it requires that the causal mechanism that generates capacity be specified. Whisky has the capacity to intoxicate because it contains alcohol, a pharmacological agent that affects certain neurotransmitter and neuropeptide systems in the brain, with behavioural and symptomatic effects (Vengeliene et al. 2009). In the case of capabilities' disposition to produce international political power, myriad causal pathways would need to be articulated, since there are typically multiple paths from a particular capacity to an outcome in any given situational context (Guzzini, 2017).

This issue is only reinforced by the assumption of much of the power shifts debate that power can be aggregated. Whilst different elements of power are often acknowledged, the multidimensional nature of power is simultaneously and implicitly denied by an approach that holds power to be, in some fundamental sense, fungible (Guzzini, 2005). It is true that certain resources are more fungible than others - money, for example, can be useful in a variety of situations. At the same time, other resources are highly limited in their convertibility: anti-aircraft installations are designed to shoot down incoming aircraft, but of limited benefit elsewhere in the military sphere, let alone in other areas of international relations. The claim of realists that "what money is to economics, power is to international relations" (Mearsheimer, 2001, p.17) therefore does not stand up to theoretical scrutiny (Aron, 2003; Baldwin, 1989). The logical consequence of the multidimensional and non-fungible nature of power is that there is no single scale of measurement to which power interactions can be reduced, and so there can be no single international distribution of power (Guzzini, 2009).

All of which suggests that even if power is understood as a disposition, rather than as a property concept, it still makes little sense to speak about power without specifying the context, that is, at minimum, the scope and domain of the power relationship under study, as relational power approaches insist we must (Baldwin, 2016). To take the example of economic capability, Nye notes, correctly, that 'manipulating the asymmetries of interdependence is an important dimension of economic power' (Nye, 2011, p. 55), and that there is little sign of economic power existing where 'there is a symmetry in the interdependence' (Nye, 2007, p. 166), a reality that may characterize the mutually assured economic destruction of US-China debtor-creditor relations today. Yet such contextual specificities are only instrumentally engaged within the power shifts debate, which fails to engage the issues around power as a concept that they imply.

Assessing metrics, whether they are military indicators, economic data, or more qualitative measures of capability, is clearly not a useless exercise. Some indicators are of direct and very real. Military data does tell us something about a state's capacity to win a war against another state. Information about the strength of a country's companies and markets does tells us something about interests and incentives within trade negotiations. However, as Guzzini puts it, "we do not know how many inhabitants equal running one of the world's currency, or, to push the argument further, how the economic value of multi-national enterprises whose headquarters are located in a particular country can be counted as a resource in the first place" (Guzzini, 2009, p.14). Resources are often incommensurable, and the mechanisms by which capacities become power cannot be reduced to a constant.

In the late 1980s, Susan Strange wrote that "the development of quantitative techniques applies to international studies has not advanced theory. The choice of what is to be counted is too arbitrary and the determination of what is causal and what is coincidental is too subjective to provide a basis 
for explanation" (Strange, 2015, p. 11). Little has changed since, in particular in terms of assessing the relative power of states. The reason that there is so much debate around US decline, and so much room for protagonists to place their emphasis on particular metrics and trends rather than others, is because we have no empirical calculus of power with which to ascertain which capabilities really matter, and no proven standard of judgement with which to weigh different capabilities against each other. The power shifts debate wants to be able to talk about power both in the aggregate and in the abstract, that is, independent of expost observations of power behaviour. At a basic theoretical level, the concept of power participants in the debate are using is unable to do what the debate's terms asks of it.

\section{A Structural Power Approach}

As the last section demonstrated, it is impossible to arrive at an assessment of American power, or of Chinese power, in the aggregate. This takes us - properly - into the realms of theory. The realist position is that in the last resort, military capabilities are determining, and it is the balance of military capacities that is the primary driver of state behaviour. This places military power at the top of a hierarchy of capabilities, weighted above economic strength (which represents potential for rather than actual military capabilities), and other underlying factors such as population, natural resource base and organisational sophistication (Organski, 1968). In essence, such an approach views international politics as the perpetual preparation for war: a subject to which we return later.

In reality, and as we alluded to earlier, very few relationships of power are under the kind of pressure that the last resort is reached. The vast majority of the time, decisions are taken in view of a range of different pressures and incentives, and there is not necessarily any hierarchy of capabilities that creates that perspective, something evident from the reaction to Vladimir Putin's decision to arrive at the 2014 G20 summit accompanied by four warships (Leftly, 2014).

There are, however, alternative approaches to the question of whether power may be shifting in the international system. One is relational - to look for instances where power is exercised over time and see whether China increasingly gets what it wants and if the United States has to more regularly has to compromise its interests. This would have the benefit of empirically confirming that power has shifted (assuming a sample size sufficient to mitigate the issues of the exercise fallacy). Yet the aim of those thinking about decline - and those professionally engaged in the decisions that might accelerate, mitigate or reverse it - is to know if power is shifting in the present.

A second way of approaching the issue of power shifts is to think less about the particular capacities of the actors themselves, and focus more on the structures of power which they experience in common. Where relational power is context- and case-specific, structural power, on the other hand, is pervasive: it shapes the frameworks within which actors have to operate.

In the discipline of International Relations, structural power has become primarily associated with Susan Strange's image of a four-sided pyramid of structural power, in which the four planes - the production, finance, security, and knowledge structures - hold each other in place (Strange, 2015). Strange's work extended Marxist-influenced conceptions of structural power in International Political Economy that focused on the role of production (e.g. Cox, 1987), and directly critiqued claims of eroding American hegemony in the 1970s and 80s. Critics object that Strange's theory of structural power is underspecified and lacks precision (Keohane, 2000; Palan, 1999), and it is certainly true that the particular modalities of interaction between the four structures is underdeveloped in Strange's work. More fundamental criticisms of structural power as under-defined that point to the ubiquity of 'structures' in social science research - Baldwin describes a 
“conceptual morass" around the term (Baldwin 2016, p.80) - are less convincing. Joseph's 'general definition' - that to think in terms of structural power is to place primary emphasis on structures rather than agents in determining outcomes - is clear and intuitive (Joseph 2011).

A focus on structural power within the power shifts debate allows analysts to mitigate - if not completely escape - what Baldwin calls the fallacy of insufficient specification; that is, failing to adequately account for scope, domain, cost, and other aspects of context crucial to accurately identifying power (Baldwin, 2016, p.82-3). It is able to acknowledge that there is no "Power in Oshkosh", as Frederick Frey puts it, no single power structure against which actor's power may be aggregated and compared. But at the same time, by thinking in terms of structural advantage, a structural power approach allows us to point to a pervasive systematic bias in favour of a particular actor underlying any power relationships that may be specified (Frey, 1971, p. 1087).

One might object, at this point, that any assessment of structural power is likely to suffer from the same theoretical difficulties identified in the previous section - that it either equates power with its exercise or treats it as a vehicle, and that it lumps power together in the aggregate and so strips it of its necessary context. To the latter point, Strange's four structures do provide specification of both scope and domain, that is, the aspect of behaviour affected and the range of actors impacted by each aspect of structural power. To the former issue, it is the structural nature of structural power that resolves - or at least mitigates - the dilemma presented by the exercises and vehicle fallacies. Isolating structural power involves the identification of structures and processes that repeatedly impact relational power outcomes in some relatively constant way; their repeatability allows analysts to escape the exercise fallacy precisely because what is being identified is an expectation that the next time capabilities are brought to bear, the same structural conditions will apply.

This points to an important point: that structural power is prior to questions of relational power. As Strange notes, "the relative power of each party in a relationship is more, or less, if one party is also determining the surrounding structure of the relationship" (Strange, 2015, p. 27). Thus to think in terms of structural power is to emphasise the importance of historical path dependencies, institutions, norms, laws, and mechanisms of interaction. These structural conditions within which states operate creates a set of opportunities and constraints that determine the context within which direct relationships of power occur. In doing so, structural power diverts our attention away from those direct power relations themselves, and "expresses the idea that power also operates in a more indirect and diffuse way" (Konings, 2009, p.70). Those indirect pathways of influence allow structural power to be exercised institutionally, impersonally, and unintentionally (Guzzini, 1993).

So when thinking specifically about issues surrounding shifts in the balance of power between states, taking structural power seriously requires that we look beyond headline indicators, and are cautious about drawing conclusions from particular events. Instead, we should focus our attention on the deeper structural conditions of interaction, and emphasise both that those conditions may be shaped by some states more than others, and may benefit some states more than others. In doing so it is important to highlight that structural power is not an additional realm of relational interaction, in which stocks of structural power may be set against each other. To think about structural power in this way is to render it a quality of the agent, rather than a feature of the system within which agents interact.

Perhaps because of structural power's specific association with International Political Economy, and then with critical and Gramscian interpretations of IPE in particular (Gill and Law, 1989), it has been relatively neglected by researchers in international security and strategic studies, which account for much of the contemporary literature on power shifts. In making the case for a 
structural power perspective on power shifts, we come down strongly on one side of the debate in the power analysis literature between those who argue that power stops where structure begins and who emphasise the importance of assigning responsibility to an agent for any exercise of power (Lukes 2005), and those who regard the social orders and structures within which actors operate as powerful in and of themselves (Forst 2017). ${ }^{3}$

However, for the purposes of thinking about power shifts, it is not clear that we need to choose between realist and constructivist accounts of structural power. Indeed, the regularly assumed epistemological incommensurability of material and ideas-based accounts is open to question (Barkin, 2003; 2010; Kitchen, 2010). A structural power approach to power shifts should therefore pay equal attention to the importance of insights from rationalist accounts - which emphasise the intentional creation of institutional structures (Krasner, 1985) and the unintended benefits of particular structural settings (Strange, 2015) - as it does to constructivist understandings of structural power that highlight the importance of 'justification narratives' (Forst, 2017) that socialise actors and limit what can be imagined as possible within networks of collective norms (Hayward, 2018).

What is essential is that any account of how structural power works must ascertain how structures of power are established, how actors are affected by them, and how those structural power relations may be broken down (Hayward, 2018). The roots of structural power lie in relational advantage and system-making moments. When the rules, institutions, and norms of international order are up for contestation, relational power in that moment is crucial in establishing the structures from which structural power may subsequently flow. Such moments are infrequent; opportunities to establish structural power do not come along often.

The United States has been 'present at the creation' at the last three moments of systemic remaking. First, in the aftermath of the First World War, the US used its economic clout and moral superiority to demand the dismemberment of the colonial empires (Pedersen, 2015), and shape the principles and agency of economic and financial governance (Calvin, 2013). Thus, whilst the United States may have remained outside the formal structures of the League, the League of Nations system reflected US interests and ideas. When the occasion came to replace that system in the 1940s, the United States, from an unparalleled position of relational dominance, embarked on a process of system-making with renewed zeal (Ikenberry 2001; 2011).

That postwar reconstruction of international politics is the foundation of contemporary structural power. Not only did the United States create a system of security arrangements and economic regimes that cohered with American ideas and favoured US interests, in the comprehensive remaking of the German and Japanese polities the United States ensured that the principles underpinning liberal international order would be safe from challenge. Only the Soviet Union and China provided refuge from an international system that was structurally conditioned to US advantage. At the end of the Cold War, a single set of ideas had prevailed, the American system was extended, as states of the former Communist bloc were systematically integrated into Westernled economic and security institutions ( $\mathrm{Nau}, 2011)$. The neoliberal ideas of the Washington Consensus dominated the finance and production structures within the system, overwhelming favoured open-market capitalist economies; the security structure was almost universally characterised by US networks of security assistance; and the knowledge structure dominated by the legalism and intellectual property of liberal democratic states. The narrowed ideological bandwidth of the end of the Cold War period brought the rest of the world fully into alignment

\footnotetext{
${ }^{3}$ A useful discussion of the content and implications of this debate can be found in Hayward \& Lukes (2008).
} 
with the ideational and institutional frameworks created by the United States (Buzan and Lawson, 2014).

In this historic narrative, structural power is intentionally established. At specific moments of opportunity, relational advantage confers the capacity to alter the institutional setting within which future power interactions will play out. Those that experience the combination of power and opportunity to alter structural conditions - in Krasner's phrase, "to change the rules of the game" - can establish those rules in ways which confer ongoing advantage (Krasner, 1985, p. 14). This type of structural advantage may come at with associated costs of 'self-binding', but these are outweighed by the benefits of having shaped - and continuing to enjoy a preeminent position within - the settings that define and confer legitimate agency in international affairs (Ikenberry 1998; Kupchan, 1998). Indeed, Henry Nau's critique of Kennedy's declinist thesis contends that the United States' advocacy of free markets created a positive-sum economic order from which the United States derived structural benefit, precisely because others were granted autonomy within it (Nau, 1990).

Structural power persists, where relative capabilities may wax and wane, because opportunities for comprehensively remaking international order and reconfiguring the allocation of this type of institutional or 'agenda setting' power are rare. The United States has been historically lucky to have been in positions of strength at these points of opportunity to establish the ideational frameworks of international order: outside of those moments, alterations to prevailing structures have proved extremely difficult to achieve. As Charles Kupchan notes, the norms propagated by hegemonic systems are consequential: path-dependence and socialisation has ensured that the ideational packages underpinning international organisation from which structural power flows in favour of the United States have attained the status of received, unchallenged wisdom (Kupchan, 2014). The historic (im)balance of power that existed after World War II has been embedded and re-embedded within formal institutions and informal norms such that it continues to operate long after those moments have passed (Gilpin, 2002).

This points towards the idea that structural power might be as much unintentionally experienced as intentionally created, not established by force of will, but rather a direct consequence of a particular state's position in a particular domain that confers upon it particular advantages. Whilst some object to treating unintended effects as 'power' (Baldwin, 2016, p.72-5), ignoring indirect and unintended influence serves to "exclude what might well prove to be a highly significant process of control" (Dahl, 1961, p.89). As Strange puts it, "power can be effectively exercised by 'being there', without intending the creation or exploitation of privilege" (Strange, 1996, p.26). It is this sense that Pierre Trudeau memorably summarised the United States' unintentional structural power as "like sleeping with an elephant. No matter how friendly and even-tempered is the beast... one is affected by every twitch and grunt" (Trudeau, 1969). Strange was fond of the example of the US decision to raise interest rates in order to combat domestic inflation in the late 1970s, a decision that engendered more restrictive monetary policy worldwide. The sheer size and openness of US financial markets raised the prospect of massive capital flight from other economies, forcing states to amend their policies in response to the US's decision (Strange, 1986, p.55).

Here one might reasonably object that our approach structural power sails dangerously close to agentic power. If it the size of American financial markets that is causal in producing behaviour in others, surely this is relational, rather than structural, power? However, when one considers that this dominance of American financial markets is predicated on a system of open global finance in which cross-border financial flows are virtually unfettered by capital controls, it becomes less obvious that the power resides in the agent, as opposed to the agent being peculiarly advantaged by the structure within which it operates. Moreover, the distinction between what is intentional 
power and unintentional power becomes less clear: since becoming the world's largest single economy, the United States has used system-making moments to embed economic openness (Ruggie, 1982). Thus, the longer that systems persist, the greater the likelihood that the sources of advantage should be appropriately considered structural features, rather than qualities of the agent.

Indeed, global finance and production are perhaps the most significant areas where structural power shapes the conditions under which others states must operate to the advantage of the United States. It is certainly the face of structural power where most research has been undertaken, perhaps unsurprisingly given the concept's genesis in IPE. Recent research has found structural advantage in the US's centrality to global banking networks (Emmenegger, 2015; Fichtner, 2016); in the ability of its private sector banks and national treasury to create and emit excess credit (Schwartz, 2017); in US dominance of TNCs, profits, and global production flows (Phillips, 2017; Starrs, 2013; 2014; 2015); within formal financial institutions (Vestergaard and Wade, 2013); through informal dollarization (Helleiner, 2005); and of course, in the dollar's 'exorbitant privilege' of reserve currency status (Cohen, 2015; Eichengreen, 2012; Norloff 2014; Prasad 2014; Stokes, 2014). The impact of all these structural advantages is that they enable the US economy to claim a disproportionate share of global resources (Seabrooke, 2006), free from balance of payments constraints (Gowan, 1999).

The sources of this structural advantage reflect connections between intentional and unintentional power. Some of it simply derives from the size of the US economy - but under conditions of globalisation driven by US-led policies at the structural level. Aspects relate to network centrality (Hafner-Burton et. al., 2009). There is no doubt that parts flow from deliberate policy actions by the US government, which uses its relational power to augment or defend structural advantage. But perhaps most important is history: path dependencies built into the system that render adjustment to reflect changed realities very difficult. Consider that whilst the United States had overtaken Britain's GDP in the 1870s and surpassed its trade volume by 1913, the dollar did not achieve parity with sterling as the leading international currency until the 1930s. Britain's power over the coinage of sterling delayed this transition for sixty years, and it would certainly have been longer but for the massive amounts of British capital liquidated by the First World War. This is the challenge that potential rival currencies face today, but it is echoed in other areas too, from higher education to banking systems to business investment. The legacy of what's been done before provides the prevailing hegemon with structural advantages, at the same time as rendering the task of the rising challenger greater than simply achieving relational parity.

It is not only in finance and production where evidence of American structural power can be found, but research to date that explicitly invokes the concept of structural power in the areas of security (Stokes and Waterman, 2017), or knowledge (Mytelka, 2000), is relatively sparse. At the same time, Gramscian literature points to more fundamental ideational structuring of international relations. A set of neoliberal ideas about the relationship between state, society and economy, flowing out of the United States, have been absorbed by the dominant social strata of other states, including China (de Graaff and van Apeldoorn, 2017). To put it another way, as the source and beneficiary of a 'structure of values and understandings about the nature of order that permeates a whole system of states and non-state entities [and which] appear to most actors as the natural order' (Cox \& Sinclair, 1996, p. 151), the United States exercises a deep form of unconscious control over the preferences and modes of thinking of others. The ideas that underpinned the American Century are still American, though they appear ubiquitous.

There is one final, and significant, issue to be addressed, and it relates back to the underlying assumptions of relative capabilities analysis. Power transition theory, as we have already noted, views power through the lens of its ultimate arbiter: war. Historically, those moments of world- 
making which are generative of structural power have been associated with hegemonic wars, triggered by the prospect of relative decline (Gilpin, 1981). Yet today organisational and technological features of the system mitigate against the possibility of major war. On the one hand, contemporary globalisation - characterised by multinational corporations and global value chains, and of an entirely different character to previous instantiations of trade-based interdependence stabilises great power relations and has "structurally shifted the scales against any great power that tries to overturn the fundamental nature of the system through force" (Brooks, 2007, p.11). On the other, it is wildly held that the destructive power of nuclear weapons raises, perhaps prohibitively, the costs of major great power war, and creates strong disincentives down the escalatory sequence (Waltz, 1990). As Rosenau succinctly puts it, "the powerful moral stigma that attaches to nuclear weapons has tended to tarnish the use of any weapons" (Rosenau, 1990 p.194). These paralytic effects have obvious consequences for models of hegemonic change that rely on great power war as the mechanism by which shifts in relative capabilities produces a change in system leadership.

One does not have to believe that major war is impossible to regard its central place in the logic of relative capabilities assessments with some scepticism. Simply regarding such a war as intrinsically unlikely tilts the balance in favour of structural power as the overriding determinant feature of international leadership. The interplay between these two conditions of complex interdependence within capitalism and the hegemonic war supressing qualities of nuclear weapons, which render major states fundamentally secure by historic standards, suggests structural power should be more consequential in identifying hegemony. Indeed, theorists of liberal order suggest these systemic conditions favour modes of leadership characterised by the type of multi-faceted political, economic, and cultural openness associated with the American liberal project (Deudney, 2014).

\section{Conclusion: Structural Realities and Relational Perception}

How then, might US structural power be broken down? The central point of structural power is that unlike relational capabilities, its effects are pervasive and enduring. The biggest single obstacle to rising powers is the structure of the system within which they seek to rise: the technological conditions, historic patterns of behaviour, norms of conduct, regimes and institutions that order international relations. Few if any of these are continually responsive to shifts in the balance of power; and as a result we can find the memory of America's postwar predominance across the international system of today. International order, in short, has a huge amount of inertia built into it, which both mitigates against the reconfiguration of power hierarchies, and ensures that the settings within which interaction occurs disproportionately advantage those states that were at the top of the hierarchy at the last comprehensive remaking of the system.

If the analysis presented here is right, then it suggests that the decline debate's focus on power shifts, assessed in terms of trends in relative capabilities, misses a more fundamental reality about how power is manifest in international relations. We have suggested that the root of this error lies in a failure to adequately engage power as a concept. But it may not be just a question of theory. One also suspects that the latest iteration of declinism is being driven as much by the use of historical analogy as anything else. And one can understand why, given that one of the most significant laws derived from the study of world history is that all empires have a natural life cycle. They rise, they mature and in the end they all decline. The Romans did it. The Spanish did it. The British did it. And so did the USSR in the late twentieth century.

One day this will surely be true of the United States, too, although we cannot be certain today of the mechanisms by which it will come to pass. However, analysis that is predicated on relative capabilities, and ignores or underplays the importance of structural power, is likely to be premature 
in its identification of decline. It is likely to identify China as having achieved parity with the United States simply in terms of the resources available to Beijing, without acknowledging that the systemic context in which it is able to deploy its power is tilted in favour of Washington. At any point in a poker game where the chip pots are even, one player retains the advantage if the deck is stacked.

Nonetheless, there is clearly a relationship between relational and structural power. As China's relative strength grows, so too will its direct capacity to shape international outcomes, as well as its unintentional structural power. Most ASEAN members today know what it feels like to be Canada, in bed with an elephant. But China's capacity to intentionally create structural power will remain limited to the opportunities those in control of the rules of the status quo are prepared to allow it. In the absence of a world-making moment - a possibility rendered historically unlikely with the apparent obsolescence of great power war - Beijing will remain a rule-taker.

If, as we have suggested, there is a serious mismatch between what capabilities-based assessments might indicate about the trajectory of America's global position and the reality of international leadership, what might explain the current sense of declinism manifest in the United States? If our analysis here suggests that structural power has been less obvious to the discipline of International Relations, it is likely virtually invisible to millions of ordinary Americans for whom life has clearly got more difficult over the past fifteen years. Whilst the United States' ability to socialise its citizens and others into its value system is usually thought of as an asset, the vision of America as an inexorably successful nation comes under strain when the fruits of that success aren't being felt by most Americans. It is this that then opens a space for those - like Trump - who would turn patriotism into nationalism, tell Americans that America is on the slide, and offer a zero-sum approach to international order as the cure. If Washington's commitment to and defence of a system which confers it with structural advantage continues to wane, as it has so precipitously since 2016, the United States may hand others the opportunity to redesign the rules of the game. 


\section{BIBLIOGRAPHY}

Ali, T. (2003). Re-Colonizing Iraq. New Left Review, 21.

Altman, R. C., \& Haass, R. N. (2010). American Profligacy and American Power: The Consequences of Fiscal Irresponsibility. Foreign Affairs, 89, 25-0_9.

Baldwin, D.A., (1989). Paradoxes of power. Basil Blackwell.

Baldwin, D.A., (2016). Power and International Relations: A conceptual approach. Princeton University Press.

Barkin, J.S., (2003). Realist Constructivism. International Studies Review, 5, pp.325-342.

Barkin, J.S., (2010). Realist Constructivism, Cambridge University Press.

Beckley, M. (2011). China's century? Why America's edge will endure.

Beckley, M. (2018). Unrivaled: Why America Will Remain the World's Sole Superpower. Cornell

University Press.

Bremmer, I. (2012). Every nation for itself: winners and losers in a G-zero world. New York: Portfolio/Penguin.

Brooks, S. G. (2007). Producing security: Multinational Corporations, Globalization, and the Changing Calculus of Conflict. Princeton University Press.

Brooks, S. G., \& Wohlforth, W. C. (2016). The Rise and Fall of the Great Powers in the Twentyfirst Century: China's Rise and the Fate of America's Global Position. International Security, 40(3), 7-53.

Burbach, R., \& Tarbell, J. (2004). Imperial overstretch: George W. Bush and the hubris of empire. New York: Palgrave Macmillan.

Buzan, B. (2011). A World Order Without Superpowers: Decentred Globalism. International Relations, 25(1), 3-25.

Buzan, B., \& Lawson, G. (2014). Capitalism and the emergent world order. International Affairs, 90(1), 71-91.

Clavin, P. (2013). Securing the World Wconomy: the Reinvention of the League of Nations, 1920-1946.

Oxford University Press.

Cohen, B.J., (2015). Currency power: Understanding monetary rivaly, Princeton, NJ: Princeton

University Press.

Cohen, E. (2017). Is Trump Ending The American Era?. The Atlantic.

Cox, M. (2001). The New Liberal Empire: US Power in the Twenty-First Century. Irish Studies in International Affairs, 12, 39-56.

Cox, M. (2001b). Whatever Happened to American Decline? International Relations and the New United States Hegemony. New Political Economy, 6(3): p. 311 - 340.

Cox, M. (2007). Is the United States in decline-again? An essay. International Affairs, 83(4): p. 643-653.

Cox, M. (2011). Power Shift and the Death of the West? Not Yet!. European Political Science.

Cox, R. W. (1987). Production, Power, and World Order: Social forces in the Making of History. New

York. Columbia University Press.

Cox, R. W., \& Sinclair, T. J. (1996). Approaches to world order. Cambridge: Cambridge University Press.

Dahl, R.A., (1961). Who Governs? Democracy and Power in an American City. New Haven, CT: Yale University Press.

de Graaff, N. \& van Apeldoorn, B., (2017). US elite power and the rise of "statist" Chinese elites in global markets. International Politics, 54(3), pp.338-355.

de Selincourt, A., \& Marincola, J. (2003). The Histories. Penguin UK.

Deudney, D. (2014). Hegemony, nuclear weapons, and liberal hegemony. In G.J. Ikenberry (ed), Power, order, and change in world politics. Cambridge, Cambridge University Press.

Drezner, D. W. (2009). Bad Debts: Assessing China’s Financial Influence in Great Power Politics. International Security, 34, 7-45. 
Drezner, D. W. (2014). The system worked: how the world stopped another great depression. Oxford University Press, USA.

Eichengreen, B. J. (2012). Exorbitant privilege: the rise and fall of the dollar and the future of the international monetary system. Oxford ; New York: Oxford University Press.

Emmenegger, P., (2015). The long arm of justice: U.S. structural power and international banking. Business and Politics, 17(3), pp.473-493.

Fichtner, J., (2016). Perpetual decline or persistent dominance? Uncovering Anglo-America's true structural power in global finance. Review of International Studies, 43(01), pp.3-28.

Forst, R., (2017). Normativity and Power, Oxford University Press.

Frey, F.W., (1971). Comment: On Issues and Nonissues in the Study of Power. American Political Science Review, 65(4), pp.1081-1101.

Friedberg, A. L. (1988). The Weary Titan: Britain and the Experience of Relative Decline. Princeton University Press.

Giddens A. (1979) Central Problems in Social Theory: Action, Structure, and Contradiction in Social Analysis. Berkeley: University of California Press.

Gill, S.R. \& Law, D., (1989). Global Hegemony and the Structural Power of Capital. International Studies Quarterly, 33(4), pp.475-499.

Gilpin, R. (1981). War and change in world politics. Cambridge: Cambridge University Press.

Gilpin, R. (2002). The Rise of American Hegemony. In A. Cleese \& P. K. O'Brien (Eds.), Two hegemonies: Britain 1846-1914 and the United States 1941-2001 (pp. 165-198). Aldershot; Ashgate.

Gowan, P., (1999). The global gamble: Washington's faustian bid for world dominance, London: Verso.

Gray, J. (2009). False dawn: the delusions of global capitalism (New ed.). London: Granta.

Guzzini, S., (1993). Structural Power: the limits of neorealist power analysis. International Organization, 47, pp.443-478.

Guzzini, S., (2000). The Use and Misuse of Power Analysis in International Theory. In R. Palan, ed. Global Political Economy: Contemporary Theories. London: Routledge, pp. 53-66.

Guzzini, S., (2005). From (alleged) unipolarity to the decline of multilateralism? A powertheoretical critique. DIIS Working Paper, (2005/25). Copenhagen: Danish Institute for International Studies (DIIS).

Guzzini, S., (2009). On the measure of power and the power of measure in international relations. DIIS Working Paper, (2009/28). Copenhagen: Danish Institute for International Studies (DIIS).

Guzzini, S., (2017). Power and cause. Journal of International Relations and Development, 20(4), pp.737-759.

Habermas, J. (2003). Interpreting the Fall of a Monument. Constellations, 10, 364-370.

Hafner-Burton, E. M., Kahler, M., \& Montgomery, A. H. (2009). Network analysis for international relations. International Organization, 63(3), 559-592.

Halper, S. A. (2010). The Beijing consensus: how China's authoritarian model will dominate the twenty-first century. New York: Basic Books.

Hayward, C.R., (2018). On structural power. Journal of Political Power, 11(1), pp.56-67.

Hayward, C. \& Lukes, S., (2008). Nobody to shoot? Power, structure, and agency: A dialogue. Journal of Power, 1(1), pp.5-20.

Heginbotham, E., Nixon, M., Morgan, F. E., Hagen, J., Heim, J. L., Engstrom, J. et al. (2015). The US-China Military Scorecard: Forces, Geography, and the Evolving Balance of Power, 1996-2017. Rand Corporation.

Helleiner, E. (2005). Structural Power in International Monetary Relations. EUI Working Paper, $(2005 / 10)$.

Hochschild, A.R. (2016). The ecstatic edge of politics: Sociology and Donald Trump. Contemporary Sociology, 45(6), pp.683-689. 
Hoffmann, S. (1978). Primacy or world order: American foreign policy since the cold war. New York: McGraw-Hill.

Huntington, S. P. (1988). The US-decline or renewal. Foreign Affairs, 67, pp. 76-96.

Ikenberry, G.J., (1998). Institutions, Strategic Restraint, and the Persistence of American Postwar Order. International Security, 23, pp.43-78.

Ikenberry, G.J., (2001). After victory: institutions, strategic restraint, and the rebuilding of order after major wars. Princeton, N.J.: Princeton University Press.

Ikenberry, G. J. (2011). Liberal leviathan the origins, crisis, and transformation of the American World Order. Princeton studies in international history and politics.

Inglehart, R., \& Norris, P. (2016). Trump, Brexit, and the Rise of Populism: Economic HaveNots and Cultural Backlash. HKS Faculty Research Working Paper.

Jacques, M. (2009). When China rules the world: the end of the western world and the birth of a new global order. New York: Penguin Press.

Joffe, J. (2009). The default power. Foreign Affairs, 88(5), 21-35.

Joffe, J. (2014). The Myth of America's Decline: Politics, Economics, and a Half Century of False Prophecies.

WW Norton \& Company.

Joseph, J., (2011). Structural Power. In K. Dowding, ed. Encyclopedia of Power. SAGE, pp. 637640.

Kagan, R. (1998). The Benevolent Empire. Foreign Policy, 111, 24-35.

Kennedy, P. M. (1987). The rise and fall of the great powrs: economic change and military conflict from 1500 to 2000 (1 st ed.). New York, NY: Random House.

Kennedy, P. M. (2002). The Eagle Has Landed: The New U.S. Global Military Position. Financial Times.

Keohane, R. (2000). Foreword. In: T. Lawton, J. Rosenau and A. Verdun, (eds.), Strange Power. Aldershot: Ashgate, pp. ix-xvi

Kirshner, J. (2017). America, America. Los Angeles Review of Books.

Kitchen, N., (2010). Systemic pressures and domestic ideas: a neoclassical realist model of grand strategy formation. Review of International Studies, 36, pp.117-143.

Kitchen, N., \& Cox, M. (2011). Just Another Liberal War? Western Interventionism and the Iraq War. In A. Acharya \& H. Katsumat (Eds.), Beyond Iraq: the Future of World Order (pp. 65-84). Singapore: World Scientific.

Konings, M., (2009). The Construction of US Financial Power. Review of International Studies, 35(1), pp.69-94.

Krasner, S.D., (1985). Structural conflict : the Third World against global liberalism, Berkeley : University of California Press.

Krugman, P. (2009). China's Dollar Trap. In New York Times.

Kupchan, C.A., (1998). After Pax Americana: Benign Power, Regional Integration, and the Sources of a Stable Multipolarity. International Security, 23, pp.40-79.

Kupchan, C. A. (2014). Unpacking hegemony: the social foundations of hierarchical order. In G.J. Ikenberry (ed), Power, order, and change in world politics. Cambridge, Cambridge University Press.

Layne, C. (2012). This Time It's Real: The End of Unipolarity and the Pax Americana. International Studies Quarterly, 56, 203213.

Leffler, M. P. (1992). A preponderance of power: National security, the Truman administration, and the Cold War. Stanford University Press.

Leftly, M. (2014). G20 summit: Enter Putin. Accompanied by four warships. To the sound of mockery. The Independent.

Lynch, D. (2016). The End of China's Rise: Still Powerful but Less Potent. Foreign Affairs.

Lukes, S., (2005). Power: a radical view. 2nd ed., Houndmills, Basingstoke, Hampshire, New York: Palgrave Macmillan.

Mahbubani, K. (2008). Welcome to the Asian Century. Current History, 107, 195-200. 
Mann, M. (2004). The First Failed Empire of the 21 st Century. Review of International Studies, 30. Mearsheimer, J.J., (2001). The tragedy of great power politics. New York, London: W.W. Norton.

Merritt, R.L. and Zinnes, D.A. (1988). Validity of Power Indices. International Interactions 14(2): $141-51$.

Morgan, I. W. (2009). The age of deficits: presidents and unbalanced budgets from Jimmy Carter to George W. Bush. Lawrence, Kan.: University Press of Kansas.

Morriss, P., (2002). Power: A Philosophical Analysis 2nd ed., Manchester: Manchester University Press.

Murphy, C. (2007). Are we Rome?: the fall of an empire and the fate of America. Boston: Houghton Mifflin Co.

Mytelka, L.K. (2000). Knowledge and structural power in the international political economy. In J. N. Rosenau, A. C. Verdun, \& T. C. Lawton, eds. Strange Power. Ashgate, pp. 39-56.

Nau, H. R. (1990). The Myth of America's Decline: Leading the World Economy into the 1990s. New York: Oxford University Press.

Nau, H. R. (2001). Why 'the rise and fall of the great powers' was wrong. Review of international studies.

Nau, H. R. (2011). Ideas have consequences: The Cold War and today. International Politics, 48(45), 460-481.

Norrlof, C. (2010). America's global advantage: US hegemony and international cooperation. Cambridge: Cambridge University Press.

Norrlof, C., (2014). Dollar hegemony: A power analysis. Review of International Political Economy, 21(5), pp.1042-1070.

Nye Jr, J. S. (2015). Is the American Century Over? John Wiley \& Sons.

Nye, J.S. (2007). Notes for a Soft Power Research Agenda. In F. Berenskoetter \& M. J. Williams (Eds.), Power in world politics. Routledge.

Nye, J. S. (2011). The future of power (1st ed.). New York: Public Affairs.

Obama, B. (2016). Remarks by the president in state of union address. The White House, Office of the Press Secretary.

Organski, A. F. K. (1968). World politics (2d ed.). New York,: Knopf.

Palan, R. (1999). Susan Strange 1923-1998: A Great International Relations Theorist. Review of International Political Economy, 6(2), pp. 121-132.

Pedersen, S. (2015). The Guardians: the League of Nations and the Crisis of Empire. OUP Oxford.

Phillips, N., (2017). Power and inequality in the global political economy. International Affairs, 93(2), pp.429-444.

Posen, B. (2003). Command of the Commons: The Military Foundation of U.S. Hegemony. International Security, 28, 5-46.

Prasad, E. (2014). The Dollar Trap: How the U.S. Dollar Tightened Its Grip on Global Finance. Princeton University Press.

Quah, D. (2011). The Global Economy's Shifting Centre of Gravity. Global Policy, 2, 3-9.

Rachman, G. (2011). Think Again: American Decline - This Time It's for Real. Foreign Policy, $\mathrm{Jan} / \mathrm{Feb}$.

Romney, M. (2010). No apology: The case for American greatness. Macmillan.

Rosenau, J. N. (2018). Turbulence in World Politics: A Theory of Change and Continuity. Princeton

University Press.

Ruggie, J. G. (1982). International Regimes, Transactions, and Change: Embedded Liberalism in the Postwar Economic Order. International organization, 36(2), 379-415.

Schwartz, H.M., (2017). Elites and American structural power in the global economy. International Politics, 54(3), pp.276-291.

Starrs, S.K. (2013). American Economic Power Hasn't Declined-It Globalized! Summoning the Data and Taking Globalization Seriousl. International Studies Quarterly. 
Starrs, S.K., (2015). China's Rise is Designed in America, Assembled in China. China's World, 2(2), pp.9-20.

Starrs, S.K., (2014). The Chimera of Global Convergence. New Left Review, 87, pp.81-96.

Stiglitz, J. (2012). The price of inequality. Penguin UK.

Stiglitz, J. E., \& Bilmes, L. J. (2008). The three trillion dollar war: The true cost of the Iraq conflict. WW Norton \& Company.

Stokes, D., (2014). Achilles' deal: Dollar decline and US grand strategy after the crisis. Review of International Political Economy, 21(5), pp.1071-1094.

Stokes, D. \& Waterman, K., 2017. Security leverage, structural power and US strategy in east Asia. International Affairs, 93(5), pp.1039-1060.

Strange, S., (1986). Casino capitalism. Oxford: Basil Blackwell.

Strange, S., (1996). The retreat of the state: the diffusion of power in the world economy. Cambridge: Cambridge University Press.

Strange, S. (2015). States and markets. Bloomsbury Publishing.

Tellis, A.J., Bially, J., Layne, C. and McPherson, M. (2000). Measuring National Power in the Postindustrial Age. Santa Monica, CA: RAND Corporation, 2000.

Trudeau, P.E. (1969). Address to the National Press Club in Washington, D.C., on US-Canada Relations. 26 March 1969.

Trump, D.J. (2017). Inaugural Address. The White House.

Vengeliene, V. et al., (2009). Neuropharmacology of alcohol addiction. British Journal of Pharmacology, 154(2), pp.299-315.

Vestergaard, J. \& Wade, R.H., (2013). Protecting Power: How Western States Retain The Dominant Voice in The World Bank's Governance. World Development, 46, pp.153-164.

Wallerstein, I. (2003). The decline of American power: The US in a chaotic world. The New Press.

Waltz, K. N. (1990). Nuclear myths and political realities. American Political Science Review, 84(3), 730-745.

Wilson, D., \& Purushothaman, R. (2003). Dreaming with Brics: The Path to 2050. New York.

Wohlforth, W. C. (1993). The elusive balance: power and perceptions during the Cold War. Cornell University Press.

Wohlforth, W. C. (1999). The Stability of a Unipolar World. International Security, 24, 5-41.

Wohlforth, W.C., (2003). Measuring Power - and the Power of Theories. In C. Elman \& J. A. Vasquez, eds. Realism and the Balancing of Power A New Debate. pp. 250-265.

Zakaria, F. (2008). The post-American world (1st ed.). New York: W.W. Norton \& Company.

Zenko, M. (2016). Republicans Won't Stop Saying Our Military Is Weak and the American public is starting to believe them. Foreign Policy. 